\title{
Comparative analysis of male calling signals in closely related species of Macropsis Lewis, 1836 (Homoptera: Auchenorrhyncha: Cicadellidae: Eurymelinae: Macropsini) reveals possible ways of evolution of the signal temporal pattern
}

\author{
Сравнительный анализ призывных сигналов самцов \\ близкородственных видов Macropsis Lewis, 1836 (Homoptera: \\ Auchenorrhyncha: Cicadellidae: Eurymelinae: Macropsini) \\ позволяет выявить возможкные пути эволющии \\ временно́го рисунка сигналов
}

\section{D.Yu. Tishechkin \\ A.Ю. Тишечкин}

\begin{abstract}
Department of Entomology, Faculty of Biology, M.V. Lomonosov Moscow State University, Vorobyevy Gory, Moscow 119234, Russia. Email: macropsis@yandex.ru

Кафедра энтомологии Биологического факультета Московского государственного университета имени М.В. Ломоносова, Воробьёвы Горы, Москва 119234, Россия.
\end{abstract}

KEY WORDS: Homoptera, Auchenorrhyncha, Cicadellidae, Macropsis, calling signals, variability, evolution.

КЛЮЧЕВЫЕ СЛОВА: Homoptera, Auchenorrhyncha, Cicadellidae, Macropsis, призывные сигналы, изменчивость, эволюция.

ABSTRACT. It is shown that, in some closely related Macropsis species, male calling signals consist of similar components but clearly differ in the duration of homologous parts, the shape of syllables, the presence/absence of additional components, or the presence/absence of gaps between the signal parts. In some other leafhoppers, such differences are intraspecific and can be observed in the signals of males from the same population and even in the same male. Thus, in the considered Macropsis species, signals were apparently formed by fixing different originally intraspecific variants in different phylogenetic lineages in the course of their divergence. This suggests that intraspecific variability can become a basis for rapid divergence of signal patterns if in different populations different pattern variants gain a selective advantage. Based on this, we can assume that male calling signals in leafhoppers can evolve not only by a gradual change in the quantitative parameters such as the signal parts duration but also through qualitative changes of temporal pattern due to adding new components, change of a syllable shape, and splitting a single signal into several parts. Since in closely related leafhopper species it is the differences in signal patterns that provide reproductive isolation, such changes can result in rapid speciation.
РЕЗЮМЕ. Показано, что у некоторых близкородственных видов Macropsis призывные сигналы самцов состоят из сходных компонентов, но чётко различаются по их длительности, форме серий, наличию/отсутствию дополнительных компонентов или наличию/отсутствию пауз между частями сигнала. У ряда других видов Cicadellidae подобные различия представляют собой внутривидовые вариации, наблюдающиеся в сигналах самцов из одной популяции и даже у одного и того же самца. Это позволяет предположить, что у рассмотренных видов Macropsis сигналы сформировались за счёт фиксации разных изначально внутривидовых вариантов в разных филогенетических линиях в процессе их дивергенции. Таким образом, внутривидовая изменчивость может стать основой для быстрой дивергенции структуры сигналов, если в разных популяциях разные варианты сигнала получат селективное преимущество. При этом у цикадовых призывные сигналы могут эволюционировать не только в результате постепенного изменения количественных параметров, например, длительности частей сигнала, но и посредством качественных изменений временно́го рисунка за счёт добавления новых ком-

How to cite this article: Tishechkin D.Yu. 2020. Comparative analysis of male calling signals in closely related species of Macropsis Lewis, 1836 (Homoptera: Auchenorrhyncha: Cicadellidae: Eurymelinae: Macropsini) reveals possible ways of evolution of the signal temporal pattern // Russian Entomol. J. Vol.29. No.3. P.247-260. doi: 10.15298/rusentj.29.3.03 
понентов, изменения формы серий или разделения сигнала на несколько частей. Поскольку у близкородственных видов Cicadellidae репродуктивную изоляцию обеспечивают именно различия в структуре сигналов, подобные изменения могут привести к быстрому видообразованию.

\section{Introduction}

In many insect taxa, the male produces acoustic calling signals for attracting a conspecific female. Presently, it is common knowledge that, in such taxa, differences in calling signal patterns facilitate precopulatory reproductive isolation between closely related species. Thus, the trigger of divergence and, as a consequence, of speciation in such taxa can be the changes in the mating signal pattern.

In principle, speciation can occur by gradual change over long periods of time, or very rapidly or even instantaneously. In other words, it can occur through large-scale morphological and ecological divergence, or because of changes of single traits that directly affect reproductive isolation. Accordingly, in the genomes, it may appear as a deep and large-scale changes or affect just a few loci. Polygenic control of mating signal traits may suggest that signal patterns have diverged gradually, whereas single or few genes may imply that they can diverge more rapidly [Henry et al., 2002; Vedenina et al., 2006; Xu, Shaw, 2019].

Nilaparvata lugens (Stål, 1854) (Homoptera: Delphacidae) in the Pacific Region provides an example of a gradual change in the quantitative parameters of the signal in the course of divergence. The general scheme of signal temporal pattern in this species remains constant throughout its range. Populations differ only in pulse repetition frequency and these differences reflect genetic differentiation between them. The populations from Philippines and Australia were most difficult to hybridize in the laboratory and showed the greatest differences in pulse repetition frequency. However, in those crosses which were successful, there were no obvious indications of hybrid non-viability. Pulse repetition frequencies in hybrids showed values intermediate between and significantly different from both parental populations. Thus, differences in pulse repetition frequency is the only reproductive barrier on the current stage of divergence of these forms. This clearly indicates, that, first, the populations from Philippines and Australia represent an early stage of speciation process and, second, pre-mating ethological isolating mechanisms have begun to evolve in advance of post-mating ones [Claridge et al., 1985a]. Similar situation exists in Gomphocerinae (Orthoptera: Acrididae), since some grasshopper species producing different signals can be hybridised under laboratory conditions and hybrids are fertile [Vedenina, von Helversen, 2003].

Examples of geographic quantitative signal variation are also known in other taxa. The geographic variation of signals in North American orthopterans was described by Walker [1974]. The study of molecular, acoustic, and morphological differentiation in Gampsocleis sedakovii (Fischer von Waldheim, 1846) (Orthoptera: Tettigoniidae) from six localities in Inner Mongolia, China showed that the structure of acoustic signals is closely related to genetic differences between populations [Zhang et al., 2015]. Booij [1982] found evidence for geographic quantitative signal variation in Muellerianella (Homoptera: Delphacidae) in Western Europe.

Sometimes not geographical isolation, but differences in host specialisation results in reproductive isolation and acoustic divergence. $N$. lugens can feed on cultivated and wild rices and on Leersia hexandra Schwartz, 1788 (Poaceae), an abundant weed often growing along the edges of rice fields. Populations of $N$. lugens from rice and L. hexandra distinctly differ in pulse repetition frequency, under laboratory conditions when given a choice always preferred a mate from the own population, but can hybridize in no-choice crosses. Hybrids show signal parameters intermediate between parent populations but no obvious indications of hybrid non-viability. However, no males with "hybrid" signal parameters were found in nature. This indicates a high efficiency of the reproductive barrier between the two host races and allowed to conclude that they have already reached the level of different biological species [Claridge et al., 1985b].

Thus, the $N$. lugens species complex demonstrates examples of both allopatric (geographical) and sympatric (due to host shift) speciation. Remarkably, that in both cases only quantitative signal parameters evolve.

Similarly, in closely related species of planthoppers from the genus Ribautodelphax Wagner, 1963 (Homoptera: Delphacidae) male calling signals have rather complex, but similar temporal patterns so that signals of different species differ mostly in quantitative parameters [den Bieman, 1986]. Male calling signals of cryptic species of Enchenopa binotata (Say, 1824) complex (Homoptera: Membracidae) also demonstrate only quantitative differences. A carrier frequency of a signal is the most significant for conspecific mate recognition; differences in temporal patterns are less distinct and not so much affect the choice of male by female [Cocroft et al., 2008].

Under experimental conditions, quantitative signal parameters can change quite rapidly. Artificial bidirectional selection on pulse repetition frequency in female calls of Ribautodelphax imitans (Ribaut, 1953) (Homoptera: Delphacidae) resulted in complete divergence in this parameter without overlap between two lines after only five generations. Male choice tests after 10 generations revealed significant preference of mates from the same line [de Winter, 1992].

Under natural conditions, quantitative signal parameters also can evolve during rather short time span. Cave-dwelling planthoppers from the Oliarus polyphemus Fennah, 1973 species complex (Homoptera: Cixiidae) colonized lava tubes on several volcanoes on the Hawaii Island. In each cave system they formed sepa- 
rate biological species differing in pulse repetition period and syllable duration in male and female signals. The age of some caves is 350-500 years, the youngest cave ages 110 years. Thus, the age of species inhabiting these caves is less than $350-500$ years and is less than 110 years for the inhabitants of the youngest cave, since they could colonize a cave only after their host plant will grow on the surface above the cave and its roots on which the insects feed will penetrate into the cave [Hoch, Howarth, 1993].

Possibility of rapid qualitative changes in the signal temporal pattern may seem dubious. However, it is indirectly confirmed by hybridization experiments.

Male signals of hybrids of two species of Nephotettix (Homoptera: Cicadellidae: Deltocephalinae) turned out to be very variable and included elements of signals of both parental species [Claridge, 1985]. In the Chorthippus albomarginatus (De Geer, 1773) (Orthoptera: Acrididae: Gomphocerinae) species group novel elements and novel combinations of elements sometimes present in the songs of hybrid specimens [Vedenina, von Helversen, 2003]. In this taxon, different patterns of hybrid songs demonstrate the transition from the parental song of one species to the parental song of another one. The authors suggest that this transition probably illustrates the evolution of songs in the process of divergence and the formation of different species. Hybrid males of Stenobothrus clavatus Willemse, 1979 and S. rubicundus (Germar, 1817) (Orthoptera: Acrididae: Gomphocerinae) from Northern Greece also produced courtship songs with intermediate features between parental songs or with completely new elements [Vedenina et al., 2012].

Our study of the signals of Cicadellidae showed that, in some species, signals demonstrate considerable variability of not only duration and repetition period of signal components, but also of the general scheme of temporal pattern [Tishechkin, 2010]. Signals of males from the same sample or even signals of the same male can differ in the syllable shape or in the presence/ absence of comparatively long and elaborate components. It can be assumed that such variatiability can become a basis for rapid divergence of signal patterns and, as a consequence, speciation if in different populations different patterns gain a selective advantage and become genetically fixed. In this article, we illustrate this hypothesis by the examples of signals in several groups of closely related species of Macropsis Lewis, 1836 (Homoptera: Auchenorrhyncha: Cicadellidae: Eurymelinae: Macropsini).

\section{Material and methods}

Leafhopper vibrational calling signals were recorded by means of portable recording equipment consisting of a piezocrystal gramophone cartridge GZP-311 connected to the microphone input of a cassette recorder Elektronika-302-1 (before 2005), minidisk recorder Sony Walkman MZ-NH900 (2005-2016), or Roland R-05 wave/mp3 recorder (after 2017) via a custom-made matching amplifier. For recording, a twig of the host plant about $10-15 \mathrm{~cm}$ in length was attached to the cartridge by a rubber ring so that the cartridge needle touched the stem slightly. Then a nylon cage containing a male leafhopper was put on the twig. After a time, the male usually sat on the twig and started singing.

Oscillograms of signals were produced with Cool Edit Pro 2.1 software.

For elements of signal temporal pattern the following terms are used. Pulse is a brief elementary fragment of signal (or succession of sine waves) with rapid increase and subsequent decrease of amplitude, i.e. separated from similar fragments by amplitude minimums. Short fragments with constant temporal pattern usually repeated with regular intervals and consisting of uniform or different pulses are referred to as syllables. Any more or less prolonged signal with complex pattern (e.g. succession of similar or different syllables) is referred to as a phrase.

Data on collecting sites and temperature during recording for the signals presented on oscillograms are given in the Table. All specimens investigated are deposited in the collection of the Zoological Museum of M.V. Lomonosov Moscow State University.

\section{Results}

In the temperate zone of the Palearctic, the genus Macropsis includes a large number of cryptic species, almost indistinguishable by morphological traits. Typically, closely related species, despite their morphological similarity, have nothing in common in signal patterns. However, in some species, signals include similar or even almost identical components. Examples of such signals are considered below.

1. M. leporina Tishechkin, 1997 and M. ochotonaria Tishechkin, 1994 are two closely related species indistinguishable by morphological traits, often occurring in the same locality but dwelling on willows from different sections [Tishechkin, 1999]. In M. leporina, male calling signal is a long (up to 20-30 s) succession of short syllables alternating with 1-3 discrete pulses (Figs 1-6); occasionally, these pulses are absent (Fig. 6, the end of the oscillogram). In M. ochotonaria, calling signal is a single or repeated phrase consisting of rather low-amplitude monotonous component and of a succession of syllables alternating with single discrete pulses, almost as in M. leporina (Figs 7-12). Ranges of syllable repetition period in these two species completely overlap, but in M. ochotonaria syllable succession is usually shorter and includes no more than 10-15 syllables (Figs 7-9).

Thus, in the signal of $M$. ochotonaria, in comparison with M. leporina, an additional component (monotonous low-amplitude vibrations) is added, the shape of syllables slightly changes and their number decreases.

2. M. flavida Vilbaste, 1980, M. multa Tishechkin, 1997, M. impura (Boheman, 1847), and M. daurica 
Table. Data for recordings of calling signals of the studied species of Cicadellidae. Таблица. Данные о записях призывных сигналов изученных видов Cicadellidae.

\begin{tabular}{|c|c|c|}
\hline $\begin{array}{l}\text { Species (in the } \\
\text { same order as on } \\
\text { figures) }\end{array}$ & Locality & $\begin{array}{l}\text { Air } \\
\text { temperature } \\
\text { during } \\
\text { recording, } \\
{ }^{\circ} \mathrm{C}\end{array}$ \\
\hline $\begin{array}{l}\text { Macropsis } \\
\text { leporina Tish. }\end{array}$ & $\begin{array}{l}\text { Figs 1, 4: Russia, Chita Oblast, the mouth of Talacha River, ca. } 12 \mathrm{~km} \text { E of Urul'ga } \\
\text { Village, from Salix schwerinii E.L. Wolf. } \\
\text { Figs 2, 5: Russia, Primorsky Krai, env. Ryazanovka Village, } 12 \mathrm{~km} \text { SW of Slavyanka } \\
\text { Town, from S. schwerinii. } \\
\text { Figs 3, 6: Russia, Khabarovsk Krai, env. Obluchye Town, from S. schwerinii. }\end{array}$ & $\begin{array}{l}27 \\
22-23 \\
27\end{array}$ \\
\hline $\begin{array}{l}\text { M. ochotonaria } \\
\text { Tish. }\end{array}$ & $\begin{array}{l}\text { Figs 7-8, 10-11: Russia, Chita Oblast, the mouth of Talacha River, ca. } 12 \mathrm{~km} \text { E of } \\
\text { Urul'ga Village, from } S \text {. miyabeana Seemen. } \\
\text { Figs 9, 12: Russia, Buryatia, the Bryanka River Valley, } 12 \mathrm{~km} \text { E of Onokhoi, from Salix sp. }\end{array}$ & $20-25$ \\
\hline M. flavida Vilb. & $\begin{array}{l}\text { Russia, Amur Oblast, env. Kostyukovka Village, } 30 \mathrm{~km} \mathrm{~W} \text { of Svobodny Town, from } S \text {. } \\
\text { udensis Trautv. et C.A. Mey. }\end{array}$ & 27 \\
\hline M. multa Tish. & $\begin{array}{l}\text { Russia, Irkutsk Oblast, env. Kosaya Steppe Village, ca. } 22 \mathrm{~km} \mathrm{NW} \text { of Elantsy, from } S \text {. } \\
\text { rhamnifolia Pall. }\end{array}$ & $24-25$ \\
\hline M. impura (Boh.) & $\begin{array}{l}\text { Figs 21, 23: Russia, Volgograd Oblast, } 6 \mathrm{~km} \text { SW of Ilovlya Village, S. rosmarinifolia L. } \\
\text { in sandy steppe. } \\
\text { Fig. 24: Kyrgyzstan, Central Tien Shan Mts., the Dzhumgal River Valley, env. Chaek } \\
\text { Village, S. rosmarinifolia in the bog near the brook. }\end{array}$ & $\begin{array}{l}31-33 \\
22-23\end{array}$ \\
\hline M. daurica Tish. & Russia, Chita Oblast, env. Nizhny Tsasuchey Village, from S. nipponica Franch. et Sav. & $27-29$ \\
\hline M. notata (Proh.) & $\begin{array}{l}\text { Russia, Amur Oblast, env. Kostyukovka Village, } 30 \mathrm{~km} \mathrm{~W} \text { of Svobodny Town, from } S \text {. } \\
\text { pierotii Miq. }\end{array}$ & $22-24$ \\
\hline M. costalis (Mats.) & $\begin{array}{l}\text { Figs 32, 33, 36: Russia, Sakhalin, env. Sokol Town, from } S \text {. schwerinii. } \\
\text { Figs 34-35, 37-38: Russia, Khabarovsk Krai, env. Obluchye Town, from S. schwerinii. }\end{array}$ & $\begin{array}{l}25-27 \\
22-24\end{array}$ \\
\hline M. milkoi Tish. & $\begin{array}{l}\text { Figs 39-40: Kyrgyzstan, E slope of Ferghana Mtn. Range, Urumbash River, ca. } 15 \mathrm{~km} \\
\text { SW of Kazarman Town, from S. alba L. } \\
\text { Fig. 41: Kyrgyzstan, Turkestan Mtn. Range, Lyaylyak River, env. Katran Village, from } \\
\text { S. alba. } \\
\text { Fig. 42: Kyrgyzstan, Alay Mtn. Range, Kurshab River, } 10 \mathrm{~km} \mathrm{~N} \mathrm{of} \mathrm{Gul'cha,} \mathrm{from} S \text {. } \\
\text { alba. } \\
\text { Fig. 43: Kyrgyzstan, Chatkal Mtn. Range, env. Ala-Buka Village, from S. alba. } \\
\text { Figs 44-47: SE Kazakhstan, Karakol River, } 27 \mathrm{~km} \mathrm{~S} \mathrm{of} \mathrm{Taskesken} \mathrm{Village,} \mathrm{from} \mathrm{Salix} \\
\text { sect. Helix. }\end{array}$ & $\begin{array}{c}29 \\
31 \\
26-29 \\
22-23 \\
24-25\end{array}$ \\
\hline M. aselae Tish. & $\begin{array}{l}\text { Figs 48-49, 52-53: SE Kazakhstan, central part of Dzhungarsky Alatau Mtn. Range, } \\
\text { river gorge E of Dzhansagurov Village, from Salix sect. Helix. } \\
\text { Figs 50-51: SE Kazakhstan, the floodplain of Lepsy River } 13 \mathrm{~km} \text { S of Kolbay Village, } \\
\text { from Salix sect. Helix }\end{array}$ & 29 \\
\hline $\begin{array}{l}\text { M. megerlei } \\
\text { (Fieb.) }\end{array}$ & Russia, Moscow Oblast, Serpukhov District, env. Danki Village, from Rosa sp. & $22-25$ \\
\hline M. ornata Lindb. & $\begin{array}{l}\text { Figs 58-59, 61-62: Kazakhstan, Zailiysky Alatau Mtn. Range in the env. of Almaty, } \\
\text { from Rosa spinosissima L. } \\
\text { Figs 60, 63: Kyrgyzstan, Chatkal Mtn. Range, Sary-Cheleksky Nature Reserve, env. } \\
\text { Arkyt Village, from Rosa sp. }\end{array}$ & $\begin{array}{c}30 \\
22-23\end{array}$ \\
\hline $\begin{array}{l}\text { Handianus fartilis } \\
\text { Mit. }\end{array}$ & Russia, Saratov Oblast, $10 \mathrm{~km}$ E of Ozinki Town towards Ural'sk. & $26-27$ \\
\hline $\begin{array}{l}\text { Aconurella } \\
\text { diplachnis Em. }\end{array}$ & $\begin{array}{l}\text { Russia, Altai Mts., the Chulyshman River Valley ca. } 2-3 \mathrm{~km} \text { upstream from the mouth, } \\
\text { from Cleistogenes squarrosa (Trin.) Keng. }\end{array}$ & $26-27$ \\
\hline $\begin{array}{l}\text { Fangamamus } \\
\text { tripunctatus (Mats.) }\end{array}$ & Russia, Primorsky Krai, W shore of the Khanka Lake, $10 \mathrm{~km} \mathrm{~S} \mathrm{of} \mathrm{Tury} \mathrm{Rog} \mathrm{Village.}$ & $25-26$ \\
\hline \begin{tabular}{|l|} 
Evacanthus \\
asiaticus (Osh.)
\end{tabular} & Kyrgyzstan, Chatkal Mtn. Range, Sary-Cheleksky Nature Reserve, env. Arkyt Village. & $21-23$ \\
\hline $\begin{array}{l}\text { Limotettix } \\
\text { russeolus (Fall.) }\end{array}$ & $\begin{array}{l}\text { Russia, Moscow Oblast, Voskresensk District, env. Beloozersky Town, peat bog on the } \\
\text { shore of the lake, from Oxycoccus palustris Pers. }\end{array}$ & $25-27$ \\
\hline $\begin{array}{l}\text { Hephathus namus } \\
\text { (H.-S.) }\end{array}$ & $\begin{array}{l}\text { Figs 89, 91: Russia, Saratov Oblast, } 15 \mathrm{~km} \mathrm{NE} \text { of Ozinki Town. } \\
\text { Figs 90, 92: Russia, Orenburg Oblast, Guberlya River, } 25 \mathrm{~km} \text { W of Orsk. }\end{array}$ & $\begin{array}{c}33 \\
27-28 \\
\end{array}$ \\
\hline
\end{tabular}




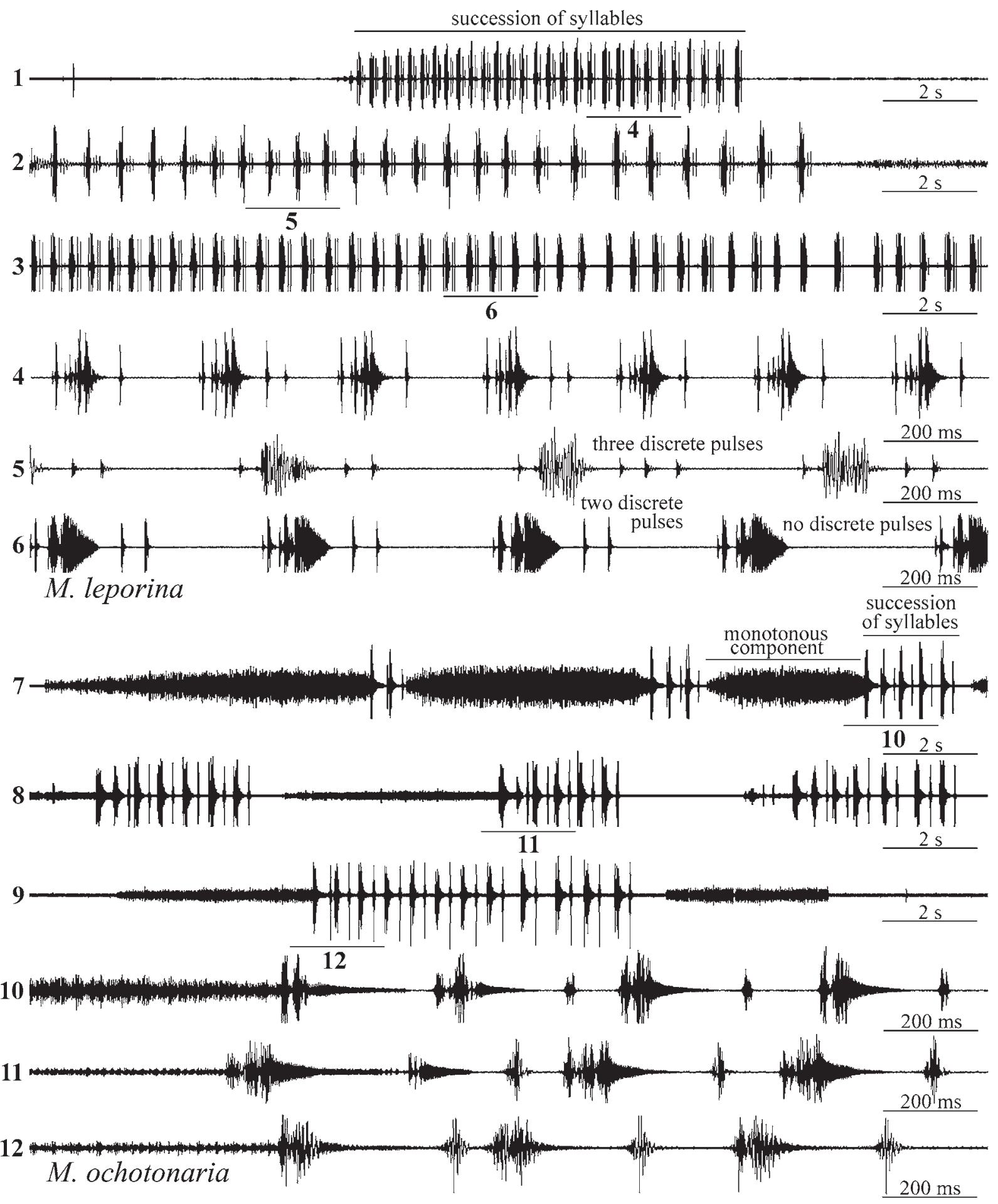

Figs 1-12. Oscillograms of male calling signals: 1-6-Macropsis leporina; 7-12-M. ochotonaria. Faster oscillograms of the parts of signals indicated as " $4-6$ " and " $10-12$ " are given under the same numbers.

Рис. 1-12. Осциллограммы призывных сигналов: 1-6 - Macropsis leporina; 7-12-M. ochotonaria. Фрагменты сигналов, обозначенные цифрами “4-6" и "10-12", представлены на осциллограммах под такими же номерами.

Figs 13-26. Oscillograms of male calling signals: 13-16 - Macropsis flavida; 17-20-M. multa; 21-23-M. impura; 24-26 $\longrightarrow$. daurica. Faster oscillograms of the parts of signals indicated as "15-16", "19-20", "23", and "25-26" are given under the same numbers.

Рис. 13-26. Осциллограммы призывных сигналов: 13-16 - Macropsis flavida; 17-20 - M. multa; 21-23 - M. impura; 24-26 - M. daurica. Фрагменты сигналов, обозначенные цифрами “15-16”, “19-20”, “23” и “25-26”, представлены на осциллограммах под такими же номерами. 


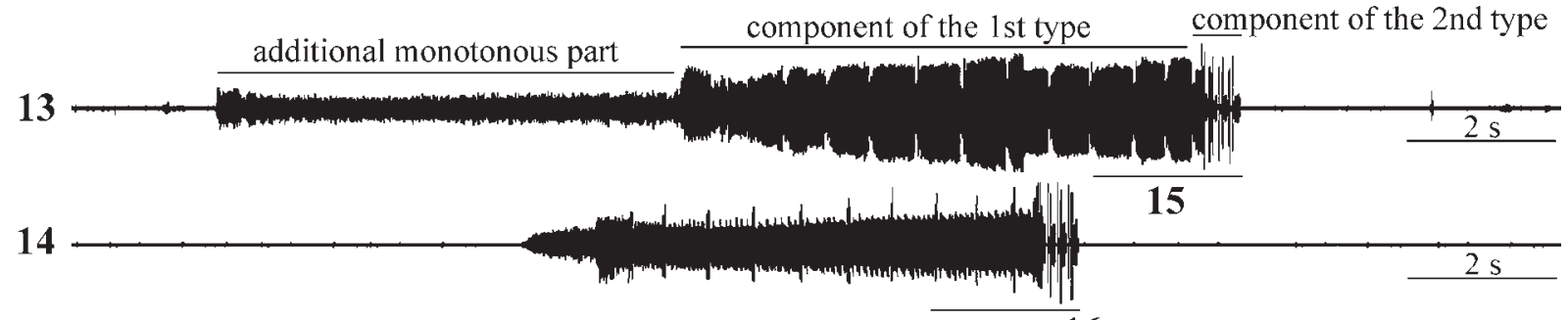

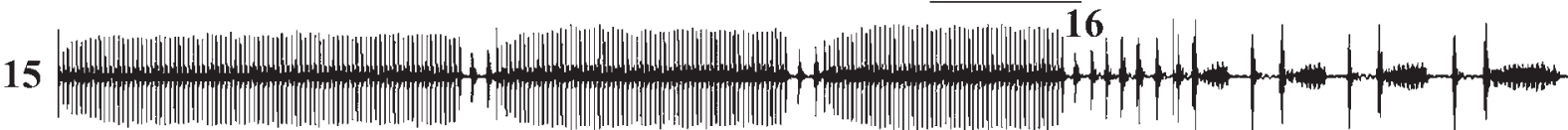

16 m. M. flavida component of the 1st type component of the 2nd type

$200 \mathrm{~ms}$

17

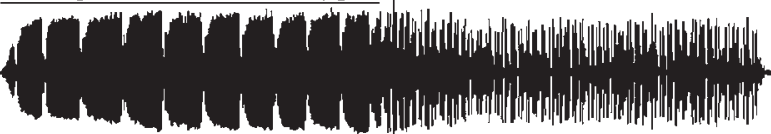

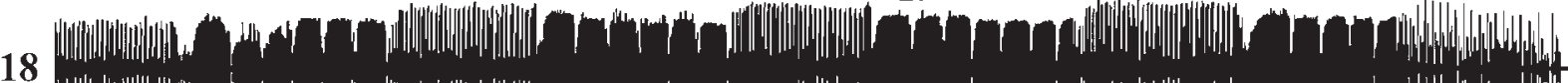
Minl

19

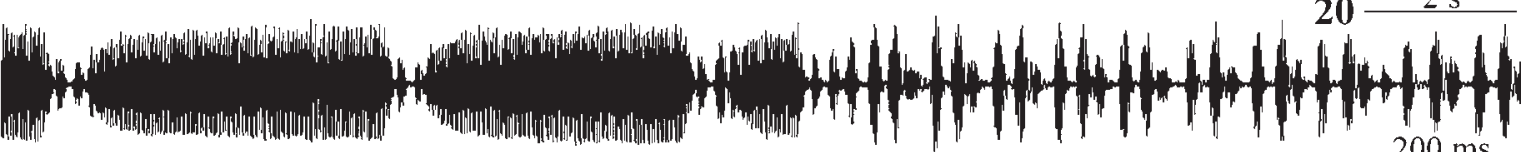

20 Inth M. multa component of the 1st type component of the 2nd type

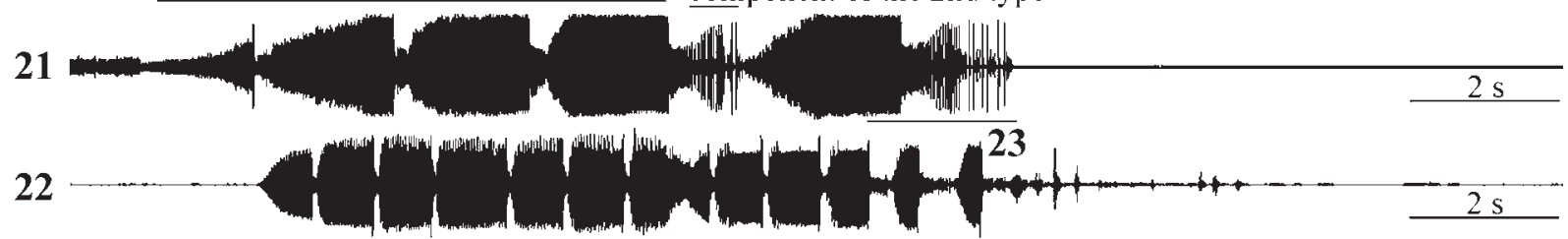

23

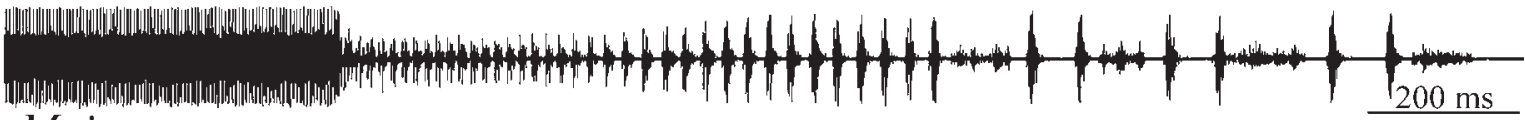
M. impura component component of the 1st type of the 2 nd type

24

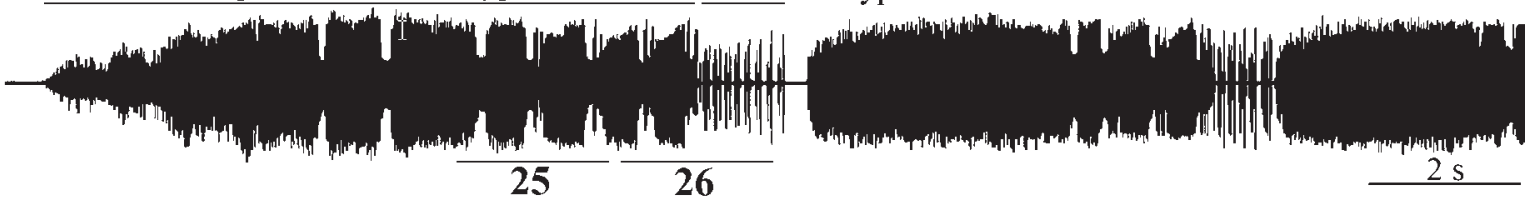
additional parts in syllables in the component of the lst type 25 Wy

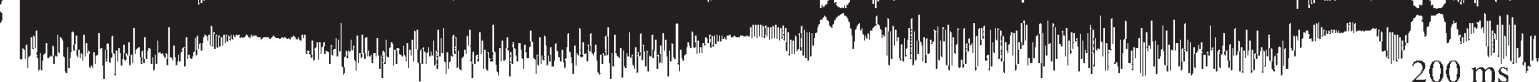

26

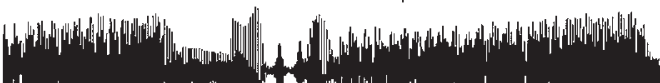

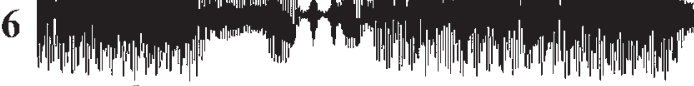
M. daurica

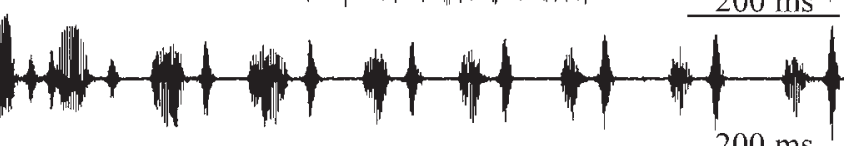


Tishechkin, 1997 belong to another group of closely related willow-dwelling species. Their relation is evidenced by the similar shape of the male $2^{\text {nd }}$ abdominal apodemes and genitalia (some species are indistinguishable by these traits), and by the shape of the $2^{\text {nd }}$ valvulae of ovipositor having 7-13 small additional teeth in all species [Tishechkin, 1999, 2002].
Signals of all these species share similar components of two types (Figs 13-26). Component of the first type is a succession of syllables separated by gaps with several discrete pulses. Component of the second type is a succession of discrete pulses; usually pulses with lower and higher amplitude alternate in it at least in the end.

succession of discrete $\quad$ succession of partially merged $\quad \begin{aligned} & \text { succession } \\ & \text { of discrete }\end{aligned}$ syllables pulses or syllables syllabl

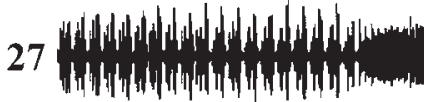

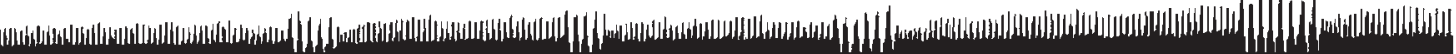
$2 \mathrm{~s}$
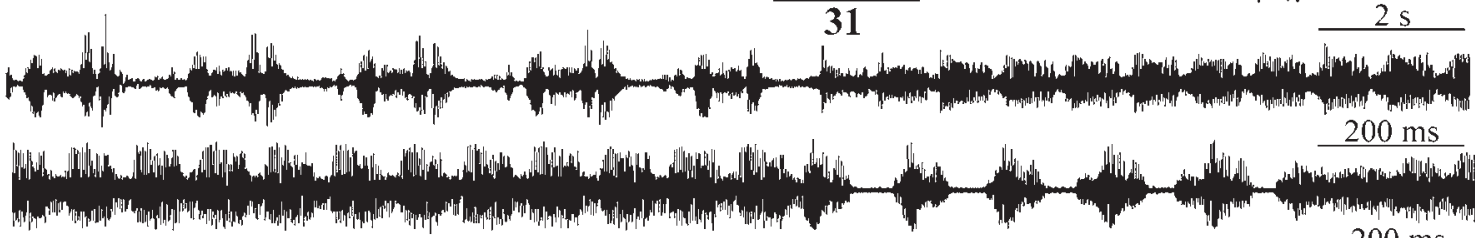

31

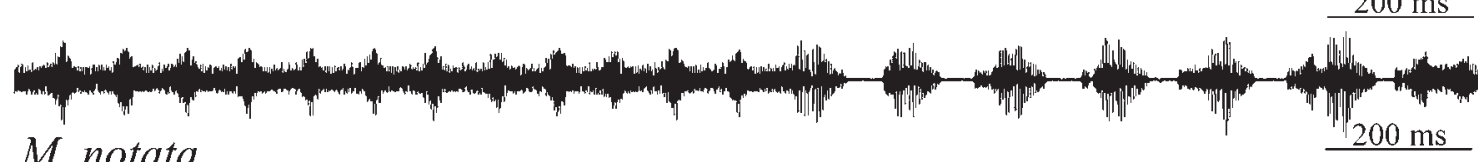

\section{M. notata}

succession of discrete

succession of partially succession syllables pulses or syllables syllables

32

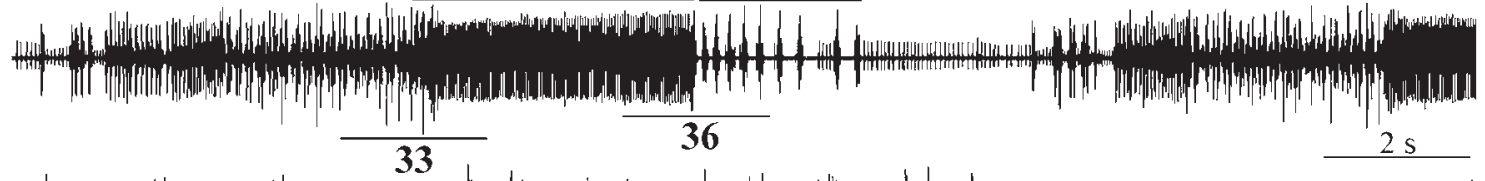

33

(n) -

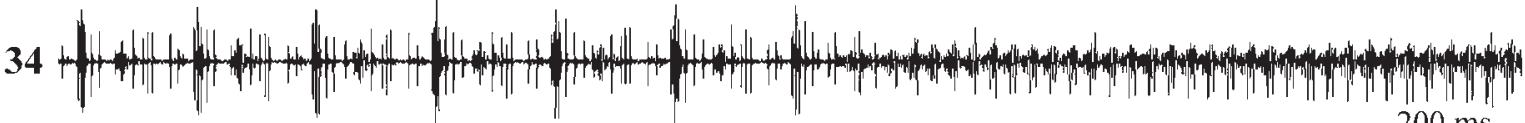
$200 \mathrm{~ms}$
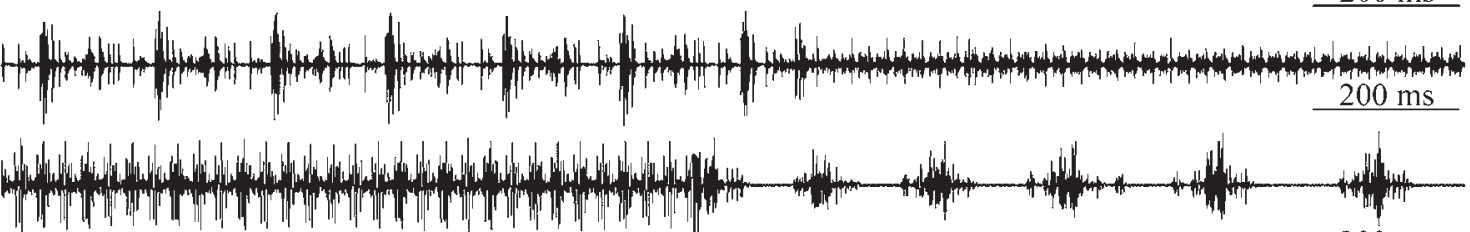
$200 \mathrm{~ms}$
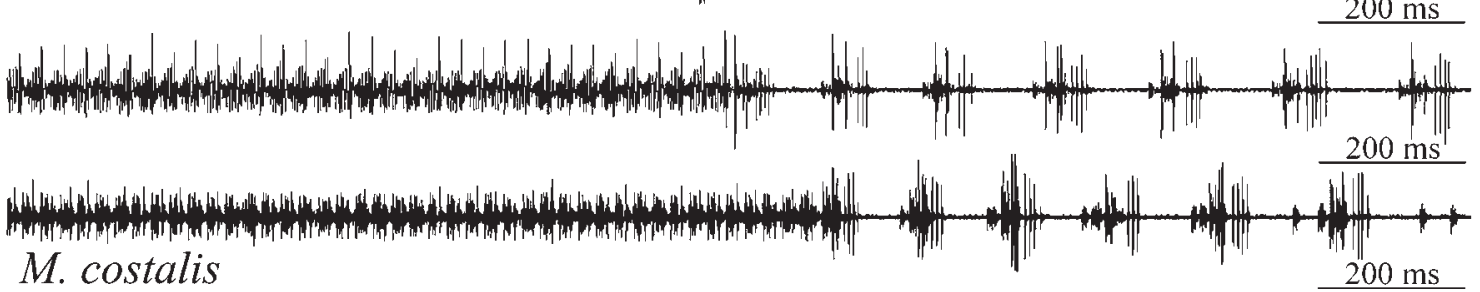

Figs 27-38. Oscillograms of male calling signals: 27-31 - Macropsis notata; 32-38 - M. costalis. Faster oscillograms of the parts of signals indicated as "29-31", "33", and "36" are given under the same numbers.

Рис. 27-38. Осциллограммы призывных сигналов: 27-31 - Macropsis notata; 32-38 - M. costalis. Фрагменты сигналов, обозначенные цифрами “29-31”, “33” и “36”, представлены на осциллограммах под такими же номерами. 


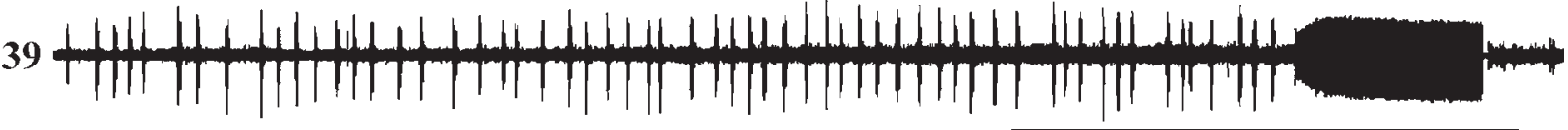
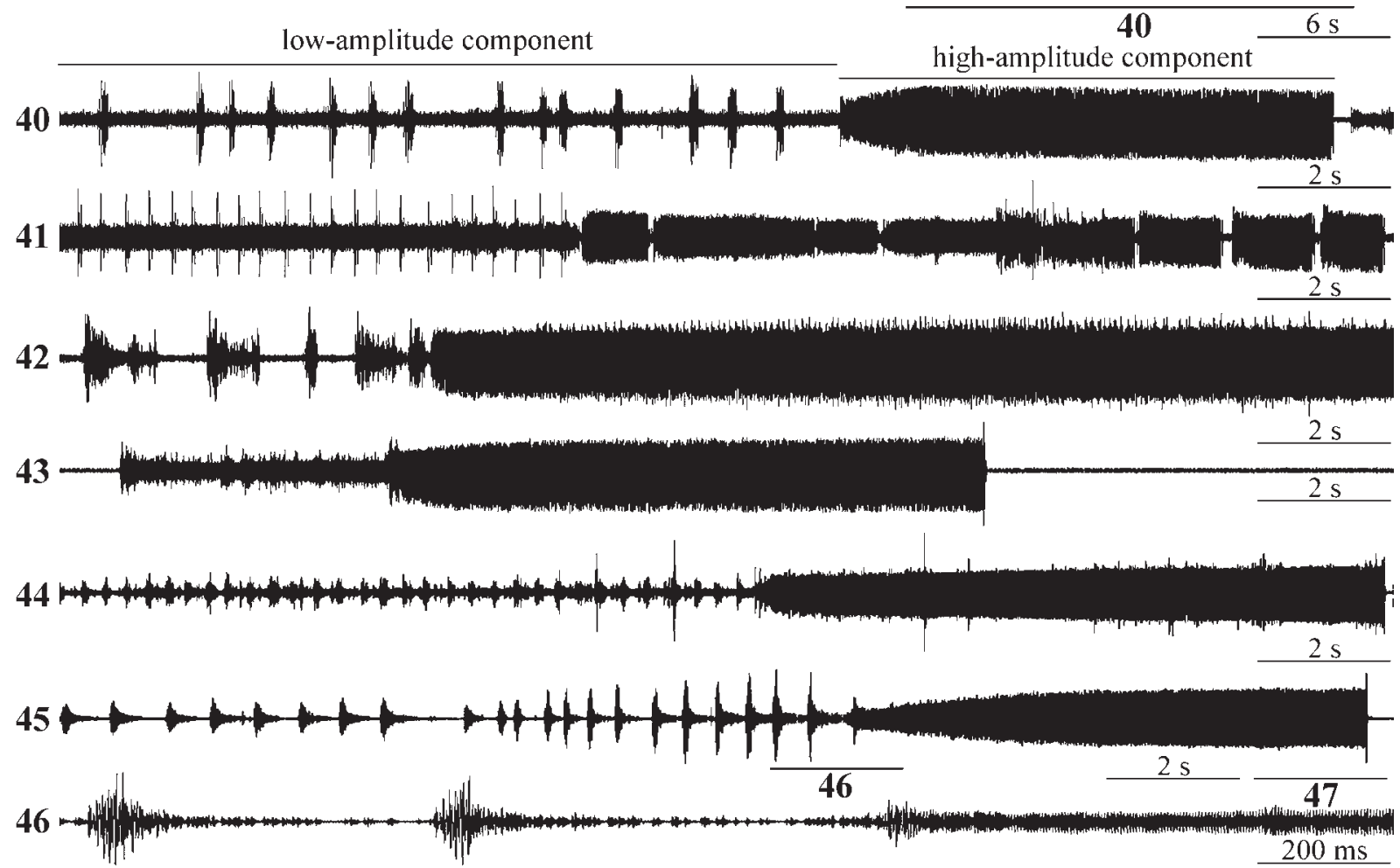

47

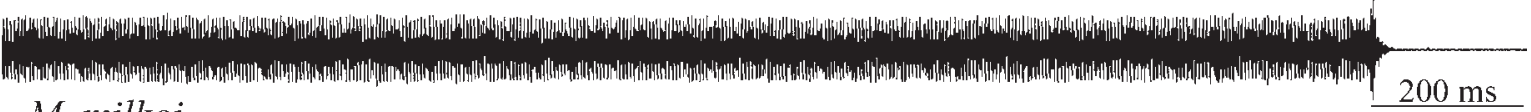

M. milkoi
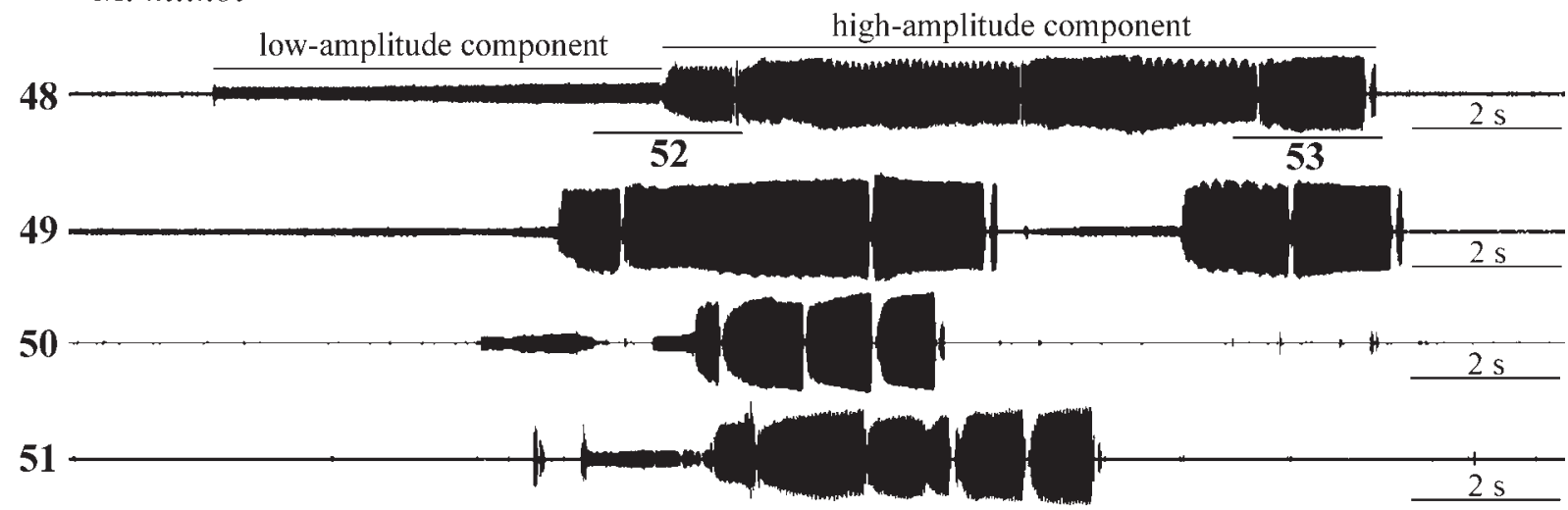

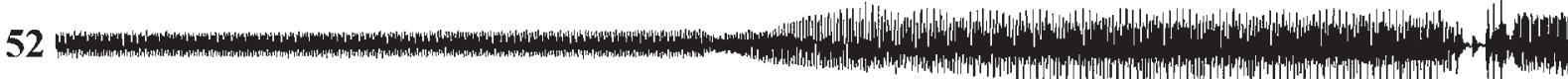

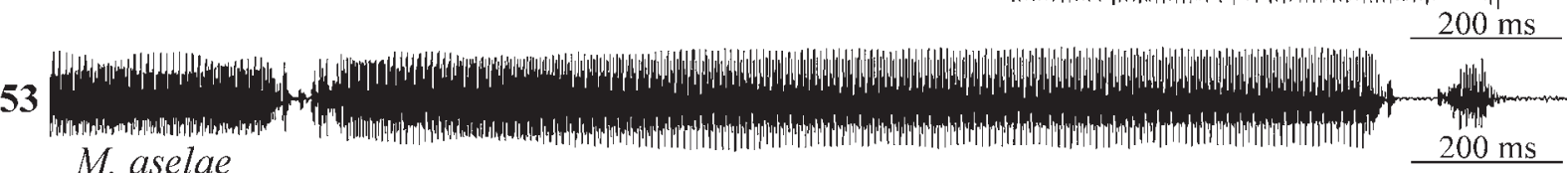

Figs 39-53. Oscillograms of male calling signals: 39-47 - Macropsis milkoi; 48-53 — M. aselae. Faster oscillograms of the parts of signals indicated as "40", "46-47", and "52-53" are given under the same numbers.

Рис. 39-53. Осциллограммы призывных сигналов: 39-47 - Macropsis milkoi; 48-53 — M. aselae. Фрагменты сигналов, обозначенные цифрами “40”, “46-47” и “52-53”, представлены на осциллограммах под такими же номерами. 
The signal of $M$. flavida usually begins with a monotonous noise-like vibrations followed by one component of the first type and one component of the second type (Figs 13-14); in the signals of all other species the initial monotonous part is always strongly reduced or absent (Figs 17, 21-22, 24). The signal of M. multa differ from signals of other species by very long component of the second type (Figs 17-20). In the signal of $M$.

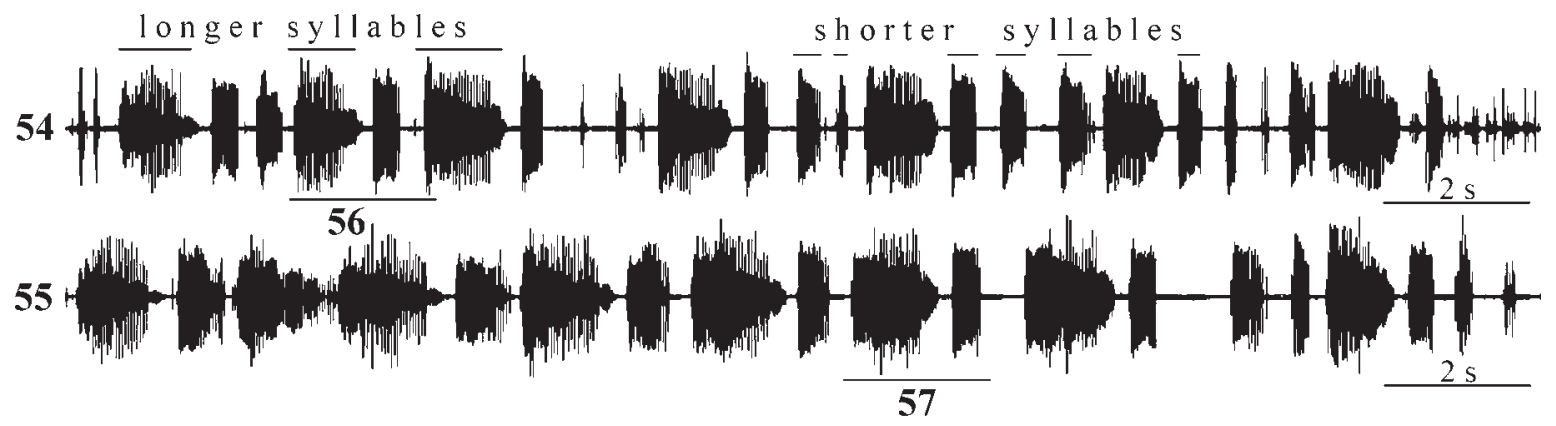

parts of sy 11 a bles

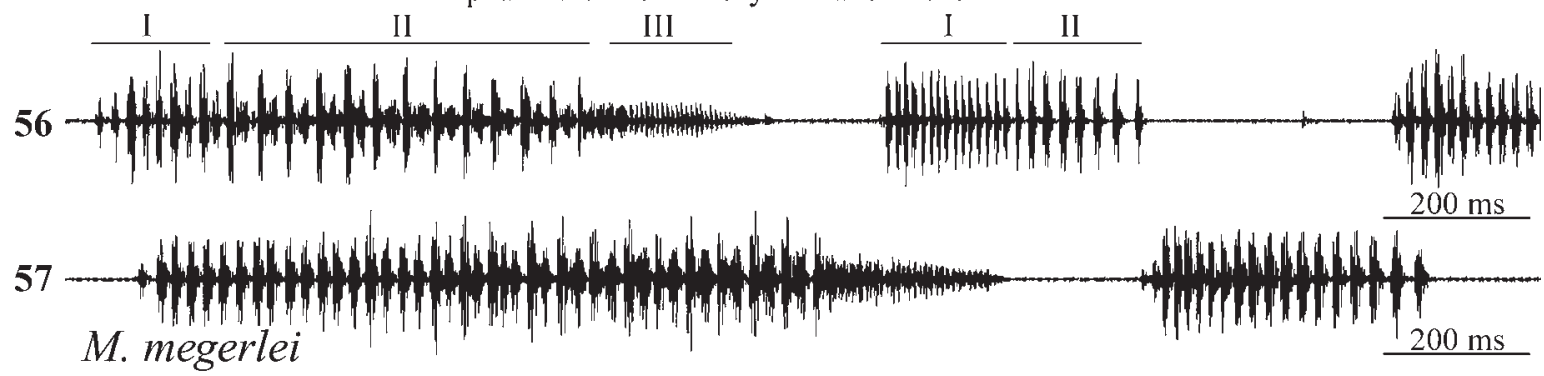
M. megerlei

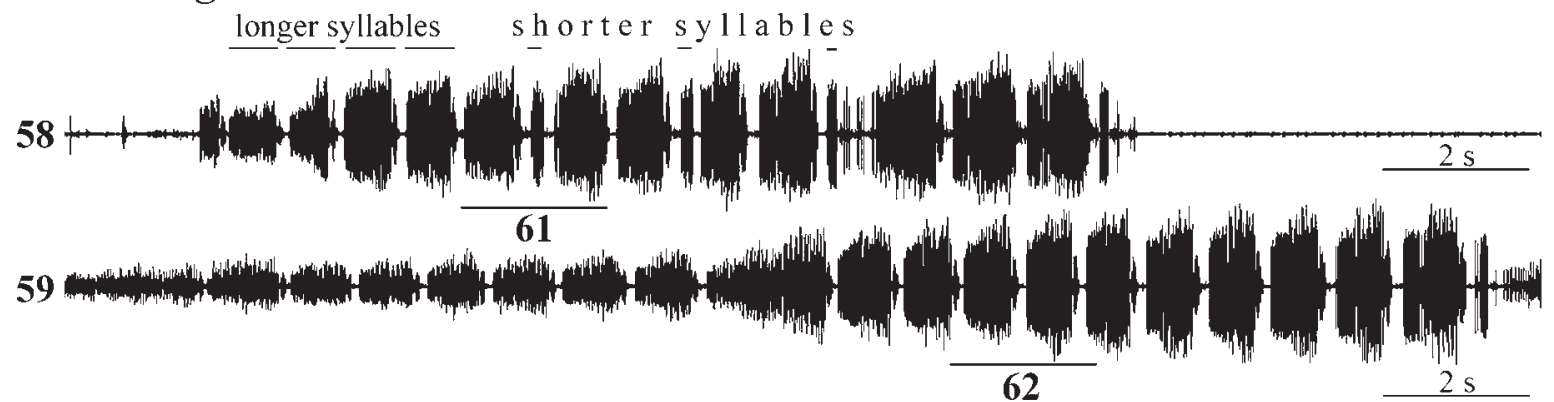

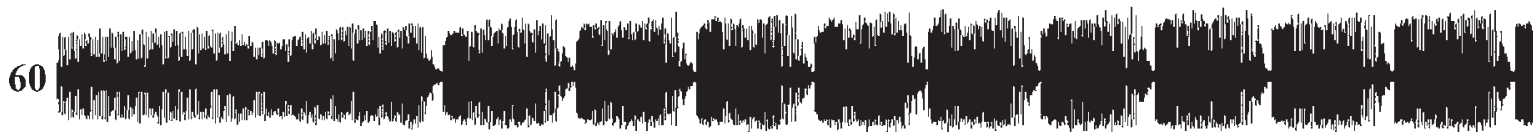
parts of s y l l a bles

63

$2 s$ I II

61 .

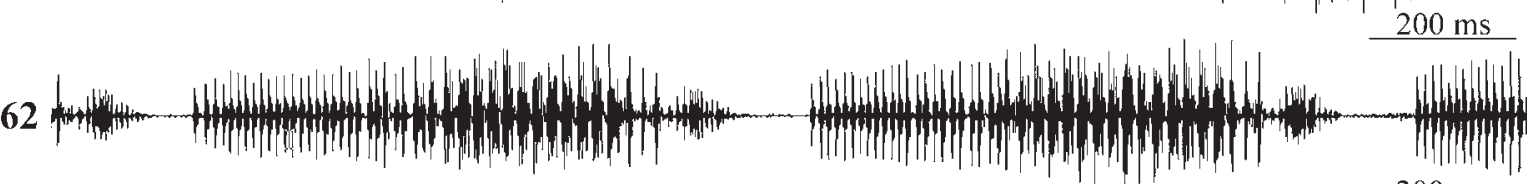

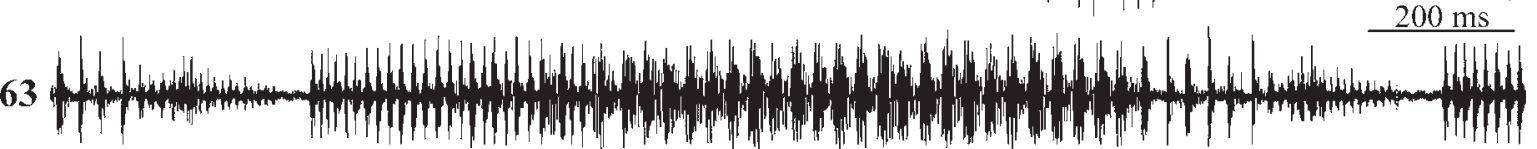
M. ornata

Figs 54-63. Oscillograms of male calling signals: 54-57-Macropsis megerlei; 58-63-M. ornata. Faster oscillograms of the parts of signals indicated as "56-57" and "61-63" are given under the same numbers.

Рис. 54-63. Осциллограммы призывных сигналов: 54-57 - Macropsis megerlei; 58-63 - M. ornata. Фрагменты сигналов, обозначенные цифрами “56-57” и “61-63", представлены на осциллограммах под такими же номерами. 
impura, the number of the second type components can vary; sometimes they are absent (Figs 21-23). In the signal of $M$. daurica, syllables in the component of the first type have an additional end part (Figs 24-26).
As a result, signals of different species in this group differ from each other, first, in the presence/absence of additional parts and, second, in the duration of homologous components.

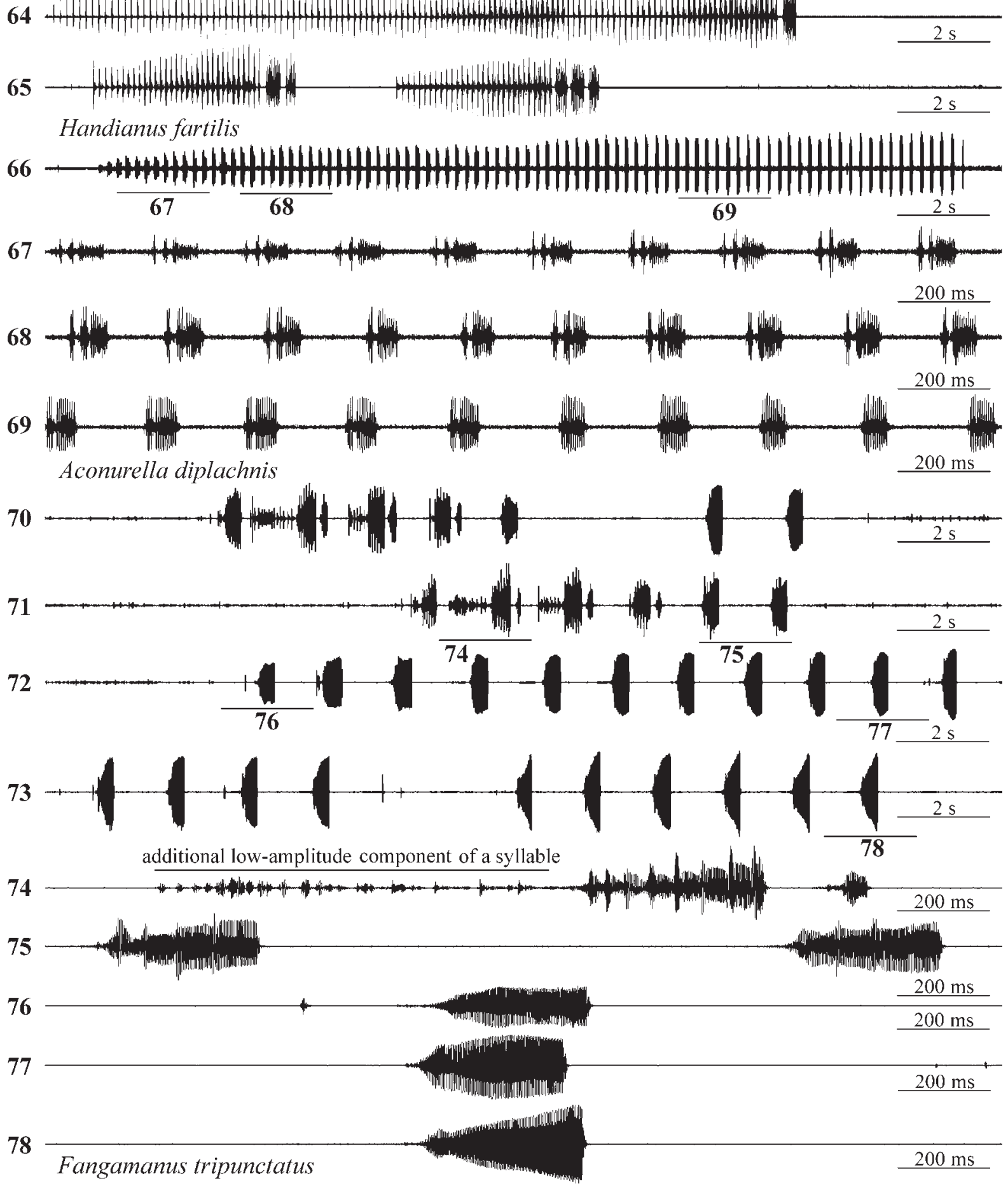

Figs 64-78. Oscillograms of male calling signals: 64-65 - Handianus fartilis; 66-69-Aconurella diplachnis; 70-78 - Fangamanus tripunctatus. Faster oscillograms of the parts of signals indicated as "67-69" and "74-78" are given under the same numbers.

Рис. 64-78. Осциллограммы призывных сигналов: 64-65 - Handianus fartilis; 66-69 - Aconurella diplachnis; 70-78 — Fangamanus tripunctatus. Фрагменты сигналов, обозначенные цифрами “67-69” и “74-78”, представлены на осциллограммах под такими же номерами. 
3. M. costalis (Matsumura, 1911) and M. notata (Prohaska, 1923) are two closely related sister-species, sympatric in the Russian Far East, but feeding on different willow species (Tishechkin, 1999). In both species, male calling signal consists of repeated phrases (Figs 27-38). The full phrase includes a succession of dis- crete syllables, a succession of partially merged pulses or syllables, and a succession of discrete shorter syllables having somewhat another shape than in the beginning of a phrase (Figs 27, 32). In M. notata, the first succession of discrete syllables in a phrase is often missed (Fig. 28).
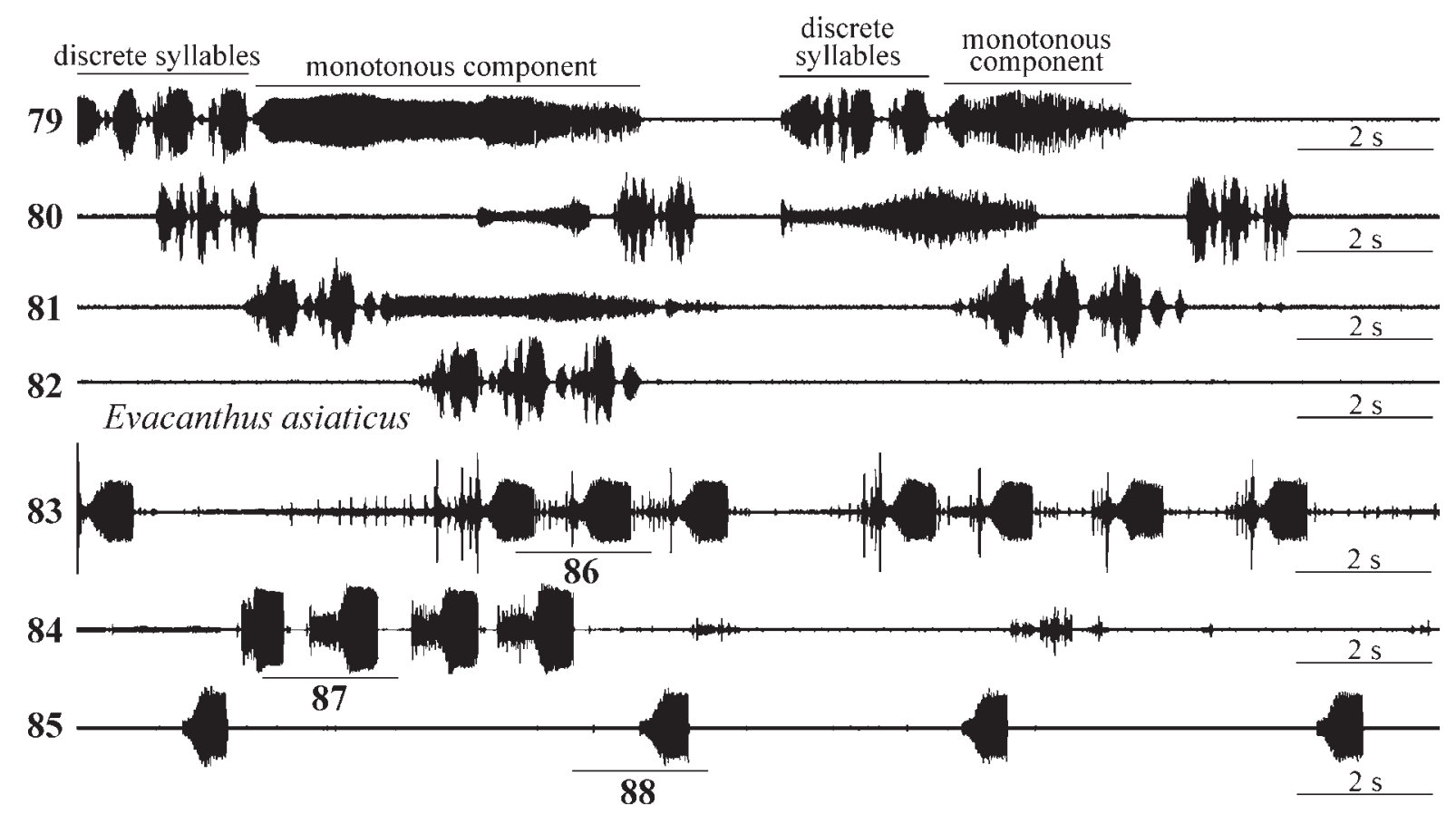
component with irregular pattern

86

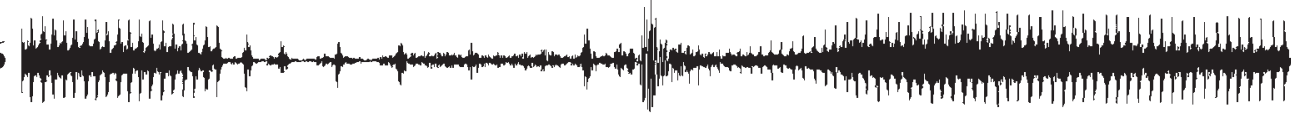

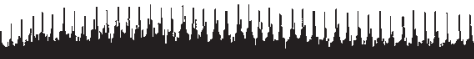

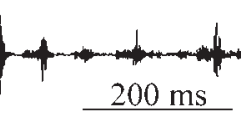

component with irregular pattern

87

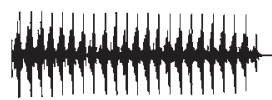

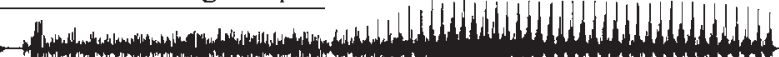

200 ms

88

Limotettix (Scleroracus) russeolus

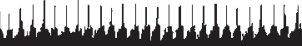

200 ms

89

$\frac{1}{91}$

$90-\frac{1}{92}$

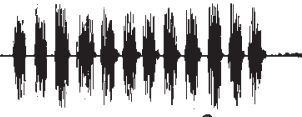

91

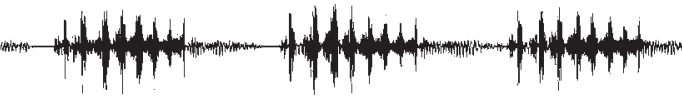

92

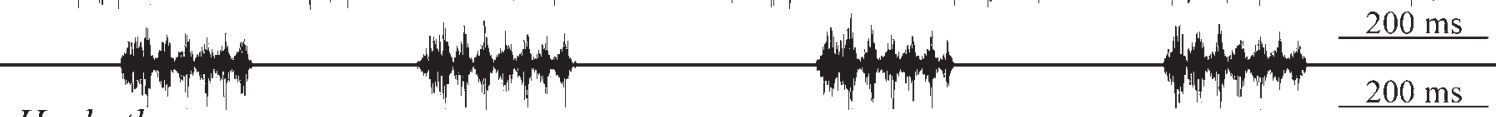

Hephathus namus

Figs 79-92. Oscillograms of male calling signals: 79-82 — Evacanthus asiaticus; 83-88 — Limotettix (Scleroracus) russeolus; 89-92 _ Hephathus nanus. Faster oscillograms of the parts of signals indicated as "86-88" and "91-92" are given under the same numbers.

Рис. 79-92. Осциллограммы призывных сигналов: 79-82 — Evacanthus asiaticus; 83-88 — Limotettix (Scleroracus) russeolus; 8992 — Hephathus nanus. Фрагменты сигналов, обозначенные цифрами “86-88” и “91-92”, представлены на осциллограммах под такими же номерами. 
Thus, in both species, phrases retain the same general pattern but differ in syllable shapes in all three parts. In addition, the initial part of the phrase is often absent in $M$. notata, whereas in $M$. costalis it is always present.

4. M. milkoi Tishechkin, 2015 and M. aselae Tishechkin, 2020 are two closely related species form Central Asia. They can feed on the same species of willows, but are allopatric. M. milkoi is widespread in Tien Shan, Pamir-Alay, and Hissar-Darvaz Mountain systems; in Kazakhstan it was also found in the plain south of Tarbagatai Range. On the contrary, M. aselae so far has only been found in the foothills and low mountains of Dzhungarsky Alatau and evidently does not penetrates far from the mountains to the plain.

In both species, male calling signal is a phrase consisting of low-amplitude and high-amplitude components (Figs 39-45 and 48-51). Both components are monotonous or slightly modulated vibrations that sound like a buzzing sound to the human ear (Figs 46-47, 5253). Durations of each component and of a phrase as a whole vary greatly, but in $M$. aselae a phrase on average is shorter and usually does not exceed $10-15 \mathrm{~s}$, whereas in $M$. milkoi it sometimes lasts for more than a minute (Fig. 39). In addition, in the first component of a phrase of M. milkoi, short syllables usually follow among lowamplitude vibrations, and the second component is a single whole; only very rarely does it split into several fragments (Fig. 41). In M. aselae, syllables in the first component of a phrase are absent, and the second component always splits into several parts separated by gaps.

Accordingly, the signals of these two species differ from each other by the presence/absence of additional syllables in the first component of a phrase, by the presence/absence of gaps in the second component, and by the average duration of phrases.

5. M. megerlei (Fieber, 1868) and M. ornata Lindberg, 1926 belong to the group of species feeding on Rosa spp. [Tishechkin, 2015]. The range of M. megerlei includes Europe, Eastern Mediterranean (Turkey, Lebanon), Transcaucasia, plains of Kazakhstan, Southern Siberia eastwards as far as the Baikal Lake, and steppes of Mongolia. M. ornata inhabits Tien Shan, PamirAlay, and Hissar-Darvaz Mountains.

Calling signal of $M$. megerlei is a succession of alternating shorter and longer syllables; it can last for a minute and more and have a comparatively constant amplitude throughout its length (Figs 54-55). Calling of $M$. ornata consists of similar syllables, but gradually increases in amplitude towards the end, thus forming a phrase with a distinct beginning and end; in addition, short syllables in it are often absent (Figs 58-60). In both species longer syllables include three, obviously, homologous parts (Figs 56-57 and 61-63). Shorter syllables in $M$. megerlei consist of two parts, whereas in M. ornata the second part is absent.

Thus, the signal of $M$. ornata has a more regular general structure and is a distinct phrase. On the contrary, in $M$. megerlei, the signal splits into separate syllables following each other in a rather irregular order and with more variable intervals; for this reason it cannot be referred to as a phrase. In addition, $M$. ornata has a clear tendency to reduction of short syllables in a phrase. Compared to M. megerlei, their number decreases, and sometimes they are completely absent; in addition, the second part is absent in them.

\section{Discussion}

As in all insects, the signals of the studied species exhibit some variability. The duration of phrases or their components varies to some extant in almost all species (for example, Figs 21-22, 48-51). The ratio of the amplitudes of different parts of the phrase is sometimes significantly different (Figs 7-8, 33-35). In some species, syllable shape also vary (Figs 4-6, 15-16, 30$31)$. In some species, the male produces certain component of a signal only occasionally, so sometimes it is absent. For example, the $M$. notata signal often lacks an initial sequence of discrete syllables (cf. Figs 27 and 28) and the $M$. ornata signal usually lacks short syllables (cf. Figs 58 and 59-60).

Despite this, signals of species under consideration always distinctly differ from each other in temporal pattern. These differences can be classified into several categories.

1. Considerable difference in the duration of the homologous parts of a signal.

2. Difference in a syllable shape.

3. Presence/absence of additional components.

4. Splitting the signal or its components into several parts in one of two sister-species.

At the same time, in other leafhoppers (Homoptera: Cicadellidae), such differences sometimes are intraspecific and can be observed between the signals of males from the same population or even in the same male [Tishechkin, 2010 and below].

Intraspecific signal variability in Handianus fartilis Mitjaev, 1975 (Figs 64-65) is basically the same as difference between signals of $M$. flavida, M. impura, and $M$. daurica on the one hand and M. multa on the other (Figs 13-14, 21-22, 24 and 17-18). In some signals of $H$. fartilis, the first part is many times longer than in others. Similarly, the main difference between signals of $M$. multa and three other species is that the end part of the signal in M. multa is much longer than in others. Signals of M. milkoi and M. aselae also differ in average durations approximately at the same level as different signals of $H$. fartilis. Similarly, signals of $M$. leporina and $M$. ochotonaria differ in a duration of a succession of syllables (Figs 1-3 and 7-9).

A gradual change of a syllable shape from the beginning to the end of a signal is observed in many species of Cicadellidae; a typical example is Aconurella diplachnis Emeljanov, 1964 (Figs 66-69). In some other species, the shape of syllables within a signal is more or less constant, whereas different signals distinctly differ in this trait; Fangamanus tripunctatus (Matsumura, 1915) can be cited as an example (Figs 70-78). It must be 
emphasized that the oscillograms on Figs 70-78 show the signals of one male recorded during the period of about half an hour.

Differences in a syllable shape between $M$. ochotonaria and M. leporina (Figs 4-6 and 10-12) and between $M$. notata and M. costalis (Figs 29-31 and 3338) generally are the same as between syllables from the beginning and from the end of a signal of $A$. diplachnis and between syllables in different signals of $F$. tripunctatus. In $M$. leporina, pulses in syllables are usually separated by distinct gaps (Fig. 4), although sometimes they merge with each other (Fig. 5). In M. ochotonaria, pulses in syllables are always partially merged (Figs 10-12). In $M$. costalis, syllables usually consist of discrete pulses (Figs 34-35, 37-38); only occasionally they partially merge with each other (Figs 33, 36). On the contrary, in $M$. notata, pulses in syllables are always merged and indistinct (Figs 29-31). Similarly, the syllables at the beginning of the $A$. diplachnis signal consist of several pulses, but short discrete pulses at the beginning of each syllable gradually reduce towards the end of a phrase (Figs 67-69). In F. tripunctatus, some syllables consist of distinct although partially merged pulses (Figs 74-75), while others are almost uniform fragments (Figs 76-78).

The appearing/reduction of an additional component of a signal is also typical of many leafhopper species. For example, in F. tripunctatus, additional low-amplitude component sometimes precedes the main part of a syllable (Figs 70-71, 74). In Evacanthus asiaticus Oshanin, 1871, a phrase normally consists of 2-4 discrete syllables followed by monotonous component (Fig. 79). However, sometimes this component is strongly reduced (Fig. 80) or absent (Figs 81, the end part of the oscillogram, 82). In Limotettix (Scleroracus) russeolus (Fallén, 1826) the phrase consists of a component with irregular pattern followed by a train of pulses (Figs 83-84, 86-87), but sometimes a male misses the irregular component (Figs 85, 88).

Similar differences are observed between the signals of the considered Macropsis species. In M. ochotonaria, compared to $M$. leporina, additional monotonous component is added to a succession of syllables (cf. Figs 1-3 and 7-9). The presence of this component is a species-specific trait of $M$. ochotonaria and is the main difference from the signal of $M$. leporina. At the same time, in E. asiaticus, the presence/absence of a similar component is observed in different signals of the same male. Signals of $M$. daurica differ from the signals of related species by the presence of an additional parts in the end of syllables (Fig. 25). One of the differences between $M$. milkoi and $M$. aselae is the presence of additional syllables in the first component of a phrase in the signal of $M$. milkoi. M. ornata differs from $M$. megerlei, inter alia, by the absence of a second part in shorter syllables and by the reduction of the number of these syllables; in some phrases they are completely absent.

Splitting the signal into separate discrete fragments was described earlier for Hephathus nanus (Herrich-
Schäffer, 1835) [Tishechkin, 2010 and Figs 89-92]. Similarly, in L. (S.) russeolus, phrases consisting of two parts usually follow one after another with short gaps (Figs 83-84, 86-87) thus forming a single signal, whereas phrases consisting only of a sequence of pulses are separated by pauses up to 5-10 s (Figs 85, 88). Similarly, in M. ornata, syllables form a distinct phrase, whereas the calling signal of $M$. megerlei is rather a succession of syllables without distinct beginning and end.

Thus, within each of the five Macropsis groups considered above, the nature of interspecific differences between signal patterns is the same as intraspecific differences in some other leafhoppers. This suggests that, in related Macropsis species, signals consisting of similar components, apparently, were formed by fixing different originally intraspecific variants in different phylogenetic lineages in the course of their divergence and a subsequent speciation. It should be added that the considered Macropsis species differ in host specialization and/or morphological traits and colouration and do not produce signals with intermediate characters. This proves that they are different biological species and not intraspecific forms.

The driving force of such signal divergence is obscure and can be different in each particular case. A study of the cryptic lacewing species (Neuroptera: Chrysopidae) suggested that the rapid divergence of their signal patterns up to the level of good species is caused by sexual selection [Henry, 1985]. Results from hybridizing of two species of Chrysopa (Neuroptera: Chrysopidae) support a key role for random mutation in species divergence, impacting mate choice immediately. It was supposed, that in this case substitution of a single allele will change the song in a major way, affecting mate choice of both males and females [Henry et al., 2002]. This confirms the hypothesis that singlegene control of signal traits may result in a rapid change of signal pattern and in a speciation.

On the other hand, for populations of Nilaparvata lugens from rice and Leersia hexandra no evidence were found that male or female signal divergence has been driven by diverging female or male preferences, respectively. Thus, these data are not consistent with sexual selection. Drift is the most likely explanation although some features of the comparison between the rice- and Leersia-feeding populations suggest the involvement of natural selection [Butlin, 1996].

Underlying genetic mechanism of signal variability in species studied is also unknown. Differences in signal patterns between different Macropsis species are obviously genetically fixed. Differences between songs of different males from the same population can also be explained by genetic differences between them. However, differences between signals of the same male (as on Figs 70-78) evidently has no relation to genetic polymorphism.

Anyway, the above examples support the assumption that male calling signals in leafhoppers can evolve not only by a gradual change in the quantitative parameters such as signal parts duration, but also through 
qualitative changes of temporal pattern due to adding/ reduction of rather large components, change of a syllable shape, or by splitting the signal or its components into several parts. Since it is the differences in the signal pattern that provide reproductive isolation, such changes can result in a rapid speciation. This can well occur if any signal trait is controlled by only one or few genes; this possibility is also confirmed by experimental data on the change of the signal pattern in hybrids. Morphological traits do not necessarily have to be involved in this process; if they remain unchanged, cryptic species are evolved.

Acknowledgements. The study was carried out in the framework of the Russian State program No. AAAA-A16116021660095-7 with the support of Russian Foundation for Basic Research, grant No. 19-04-00073 and of Moscow State University Grant for Leading Scientific Schools "Depository of the Living Systems" in frame of the MSU Development Program.

\section{References}

Booij C.J.H. 1982. Biosystematics of the Muellerianella complex (Homoptera, Delphacidae), interspecific and geographic variation in acoustic behaviour // Zeitschrift Tierpsychol. Vol.58. No.1. P.31-52.

Butlin R.K. 1996. Co-ordination of the sexual signalling system and the genetic basis of differentiation between populations in the brown planthopper, Nilaparvata lugens // Heredity. Vol.77. P.369-377.

Claridge M.F. 1985. Acoustic behavior of leafhoppers and planthoppers: species problems and speciation // Nault L.R., Rodriguez J.G. (eds.). Leafhoppers and planthoppers. Wiley \& Sons. P.103-125.

Claridge M.F., Den Hollander J., Morgan J.C. 1985a. Variation in courtship signals and hybridisation between geographically definable populations of the rice brown planthopper, Nilaparvata lugens (Stål) // Biological Journal of the Linnean Society. Vol.24. P.35-49.

Claridge M.F., Den Hollander J., Morgan J.C. 1985b. The status of weed-associated populations of the brown planthopper Nilaparvata lugens (Stål) - host race or biological species? // Zoological Journal of the Linnean Society. Vol.84. P.77-90.

Cocroft R.B., Rodrígues R. L., Hunt R.E. 2008. Host shifts, the evolution of communication, and speciation in the Enchenopa binotata species complex of treehoppers // Tilmon K.J. (ed.). Specialization, Speciation, and Radiation - The Evolutionary Biology of Herbivorous Insects. Berkeley: University of California Press. Ch.7. P.88-100.
De Winter A.J. 1992. The genetic basis and evolution of acoustic mate recognition signals in a Ribautodelphax planthopper (Homoptera, Delphacidae) 1 . The female call // Journal of evolutionary Biology. Vol.5. P.249-265.

den Bieman C.F.M. 1986. Acoustic differentiation and variation in planthoppers of the genus Ribautodelphax (Homoptera, Delphacidae) // Netherlands J. Zool. Vol.36. No.4. P.461-480.

Henry C.S. 1985. Sibling species, call differences and speciation in green lacewings (Neuroptera: Chrysopidae: Chrysoperla) // Evolution. Vol.39. No.5. P.965-984

Henry C.S., Wells M.L.M., Holsinger K.E. 2002. The inheritance of mating songs in two cryptic, sibling lacewing species (Neuroptera: Chrysopidae: Chrysoperla) // Genetica. Vol.116. P.269-289.

Hoch H., Howarth F.G. 1993. Evolutionary dynamics of behavioural divergence among populations of the Hawaiian cave-dwelling planthopper Oliarus polyphemus (Homoptera: Fulgoroidea: Cixiidae) // Pacific Sci. Vol.47. No.4. P.303-318.

Tishechkin D.Yu. 2010. On the variability of the temporal pattern of vibrational calling signals in leafhoppers (Homoptera: Cicadellidae) // Russian Entomological Journal. Vol.19. No.1. P.31-40.

Tishechkin D.Yu. 1999. Review of the species of the genus Macropsis Lewis, 1834 (Homoptera: Cicadellidae: Macropsinae) from the Russian Far East and adjacent territories of Transbaikalia // Russian Entomological Journal. Vol.8. No.2. P.73-113.

Tishechkin D.Yu. 2002. Review of the species of the genus Macropsis Lewis, 1834 (Homoptera, Cicadellidae, Macropsinae) from European Russia and adjacent territories // Russian Entomological Journal. Vol.11. No.2. P.123-184.

Tishechkin D.Yu. 2015. Taxonomic study of Central Asian species of the genus Macropsis Lewis, 1836 (Homoptera: Auchenorrhyncha: Cicadellidae: Macropsinae). III: Descriptions of two new willow-dwelling species, new synonym, annotated checklist, and key to species // Zootaxa. Vol.3985. No.1. P.31-52.

Walker T.J. 1974. Character displacement and acoustic insects // American Zoologist. Vol.14. P.1137-1150.

Vedenina V.Yu., von Helversen O. 2003. Complex courtship in a bimodal grasshopper hybrid zone // Behavioral Ecology and Sociobiology. Vol.54. P.44-54.

Vedenina V.Yu., Panyutin A.K., von Helversen O. 2006. The unusual inheritance pattern of the courtship songs in closely related grasshopper species of the Chorthippus albomarginatus-group (Orthoptera: Gomphocerinae) // Journal of evolutionary biology. Vol.20. No.1. P.260-277.

Vedenina V.Yu., Fähsing S., Sradnick J., Klöepfel A., Elsner N. 2012. A narrow hybrid zone between the grasshoppers Stenobothrus clavatus and S. rubicundus: courtship song analysis // Biological Journal of the Linnean Society. Vol.107. P.383-397.

Xu M., Shaw K.L. 2019. The genetics of mating song evolution underlying rapid speciation: linking quantitative variation to candidate genes for behavioral isolation // Genetics. Vol. 211. P.1089-1104.

Zhang Xue, Wen Ming, Li Junjian, Zhu Hui, Wang Yinliang, Ren Bingzhong. 2015. Acoustic, genetic and morphological variations within the katydid Gampsocleis sedakovii (Orthoptera, Tettigonioidea) // ZooKeys. Vol.529. P.105-121. 